(REVIEW ARTICLE)

\title{
Causative agents and chemotherapy for food poisoning
}

\author{
Moke Emuesiri Goodies ${ }^{1,}{ }^{*}$, Edje Kesiena Emmanuel ${ }^{1}$, Toloyai Pere-Ebi Yabrade ${ }^{2}$, Anachuna Kenneth \\ Kelechi ${ }^{3}$ and Ifezue Chiamaka Rachael 1 \\ ${ }^{1}$ Department of Pharmacology and Therapeutics, Delta State University, Abraka, Delta State, Nigeria. \\ ${ }^{2}$ Department of Medical Biochemistry, Delta State University, Abraka, Delta State, Nigeria. \\ 3 Department of Human Physiology, Delta State University, Abraka, Delta State, Nigeria.
}

Publication history: Received on 11 December 2019; revised on 20 April 2020; accepted on 28 April 2020

Article DOI: https://doi.org/10.30574/wjarr.2020.6.1.0102.o

\begin{abstract}
Food-borne diseases remain a major public health problem across the globe. This challenge is more severe in developing countries because of lack of proper personal hygiene and food safety measures. It is as a result of the intake of food or water contaminated with bacteria and/or their toxins, or with parasites, viruses, or chemicals. One way of avoiding food-borne illness is to practice proper personal hygiene and safe steps in food handling, cooking, and storage. Treatment of food poisoning includes use of antidiarrhoea, anti-emetic and antimicrobial therapy. Electrolyte replacement is also important to ensure dehydration does not occur. This review intends to explore information on the causative agents of food poisoning, as well as how drug therapy could be applied.
\end{abstract}

Keywords: Food poisoning; Causative agents; Hygiene; Toxins

\section{Introduction}

Food-borne diseases are still a major public health concern across the globe. This problem is very severe in developing countries because of lack of personal hygiene and food safety measures [1]. It was estimated that globally 600 million people (almost 1 in 10) fell ill in 2010 from eating food contaminated by these agents, resulting in 420,000 deaths. Thirty percent (30\%) of all deaths from food-borne diseases are children under 5 years of age [2]. The outcomes of food poisoning in Africa are not adequately documented and the actual burden of food poisoning is unknown due to a deficiency of surveillance systems and population-based studies

Food poisoning is defined as an illness caused by the consumption of food or water contaminated with bacteria and/or their toxins, or with parasites, viruses, or chemicals [3]. It is usually confused with food allergy and food adverse effects, which are, respectively, an immune-mediated reaction and a clinically abnormal response, ascribed to an exposure to a food or food additive [4]. It is a fallout from exposures to toxic agents present in the food which may lead to delirious effects following the reaction of the body to these agents or the food itself [5]. Contamination usually arises from improper handling, preparation, or storage of food or drinks. The routes by which these toxins gain entry to the body may be through ingestion, contact or transdermal, or inhalation.

Most common microorganisms involved in food poisoning include bacteria such as Staphylococcus aureus, Escherichia coli, Clostridium botulinum, Bacillus cereus, Vibrio cholerae, and Shigella species amongst others. Other microorganisms may also include Norovirus and Rotavirus as well as parasites such as Giardia spp. and Cyclosporidium spp. [6]. Some foods are more predisposed to in being potential carriers of food-poisoning microorganisms; they include milk, raw meat, seafood, poultry, and raw vegetables. Furthermore, substances released in foods by insects, bacteria or other living microorganisms, hence called "toxins", may also cause food poisoning [7, 8].

\footnotetext{
${ }^{*}$ Corresponding author: Moke Emuesiri Goodies
} 
The symptoms caused by food poisoning are varied from mild to severe or even fatal one such as death. General symptoms are nausea, vomiting, diarrhoea and abdominal pain, headache and sometimes fever may also occur [9]. If these symptoms continued, it would cause dehydration and electrolyte imbalance. Fatality of food poisoning increases in patients with chronic illness, dehydration and electrolyte disorders [10].

\section{Causative agents of food poisoning}

\subsection{Bacterial toxin poisoning}

Bacterial toxins are virulence elements that manipulate host cell functions and take over the control of vital processes of living organisms to favor microbial infection [11].

- $\quad$ Clostridium botulinum [12]

- Clostridium perfringens $[13,14]$

- Staphylococcus aureus [15, 16]

- Bacillus cereus $[17,18]$.

\subsection{Mycotoxin poisoning}

Mycotoxins are metabolites of fungi (molds), which cause both animal and human disease. Mycotoxins are toxic products of fungi, not mushrooms. The best known mycotoxins are aflatoxins, ergot derivatives, ochratoxin A, fumonisin, and deoxynivalenol [19].

\subsection{Phytotoxin poisoning}

Phytotoxins are toxins produced by plants. Phytotoxin poisoning occurs as a result of the intake of non-edible plants, to the consumption of insufficiently prepared plants or to plant toxins resistant to the food preparation process. Phytoxin includes alkaloids, terpenes, glycosides, tannins, and phenols [20, 21].

\subsection{Chemical food poisoning}

Chemical food poisoning occurs owing to a pre-contamination of plants or animals by heavy metals (lead, cadmium, mercury) which are consumed by humans. A wide range of clinical manifestations is seen depending on the chemical substance involved in poisoning. These toxic chemical products may be added directly during the food preparation process as have been seen in some cases $[22,23]$.

\section{Treatment of food poisoning}

Treatment of food poisoning is divided into;

- Symptomatic treatment (medications)

- Supportive therapy (Oral Rehydration Therapy)

\subsection{Symptomatic treatment}

\subsubsection{Anti-diarrhoeas}

- Absorbents (e.g. attapulgite, aluminum hydroxide): Atapulgite is an oral, non-absorbed medication that is used in the management of diarrhoea. Its mechanism is by adsorbing (binding) large numbers of bacteria and toxins and reducing the diarrhoea. Attapulgite lessens the number of bowel movements, improves the consistency of loose or watery stools, and relieves the cramping which is associated with food poisoning [24].

- Antisecretory agents (e.g. bismuth subsalicylate): Bismuth adsorbs extra water in the bowel during diarrhoea. It also adsorbs toxins and forms a protective coating for the intestinal mucosa [25].

- Antiperistaltics (e.g. loperamide): Loperamide is useful in the treatment of diarrhoea and irritable bowel syndrome because it inhibits intestinal secretion and peristalsis, thereby reducing the intestinal transit time and permitting more fluids and electrolytes to be absorbed; at rest, it improves anal sphincter tone, hence, it has minimal effect on the pain associated with irritable bowel syndrome [26]. 


\subsubsection{Anti-emetic: promethazine, metoclopramide}

Promethazine is a first-generation antihistamine. It is an $\mathrm{H}_{1}$-receptor antagonist with antiemetic and sedative properties [27]. Metoclopramide is a dopamine antagonist used to treat the symptoms of slow stomach emptying (gastroparesis). It increases the movement of the upper gastrointestinal tract without increasing secretion. It relieves symptoms such as nausea, vomiting, heartburn, a feeling of fullness after meals, and loss of appetite.

\subsubsection{Antibiotics: (e.g. tetracycline, ciprofloxacin, norfloxacin, co-trimoxazole, doxycycline, rifaximin).}

Ciprofloxacin (a fluoroquinolone) is a broad-spectrum antibiotic which_is active against both Gram-positive and Gramnegative bacteria. It inhibits bacterial cell division by inhibiting DNA gyrase, and a type II topoisomerase, topoisomerase IV, necessary to separate bacterial DNA [28].

\subsection{Supportive therapy}

Oral rehydration therapy (ORT) is a form fluid replacement useful in the prevention and treatment of dehydration, particularly in diarrhoea. It involves drinking water with modest amounts of sugar and salts, specifically sodium and potassium and this is to make up the salt water deficits and to replenish lost nutrients [29]. The risk of death associated with diarrhoea has been estimated to decrease by about $93 \%$ with use of oral rehydration solution and recommended home fluids [30].

\section{Conclusion}

The occurrence of food-borne disease still maintain a high despite our society's advances in sanitation, food preservation, and hygiene. Hence, there is need to advocate continuous practice of proper personal hygiene and safe methods in handling, cooking, and storage of our food so as to prevent food poisoning. Also, appropriate drug therapy should be employed.

\section{Compliance with ethical standards}

\section{Acknowledgments}

The authors wish to acknowledge the Medical Library of the Faculty of Basic Medical Sciences, Delta State University, Abraka, Nigeria for the support provided by easing access to bibliographic databases.

\section{Disclosure of conflict of interest}

The authors have declared that no competing interest exists.

\section{References}

[1] Amany MA. (2013). Knowledge, attitudes, and practices of food service staff about food hygiene in hospitals in Makkah area. Saudi Arabia Life Science Journal, 10(3), 1079-1085.

[2] WHO - World Health Organization. (2008). First formal meeting of the Foodborne Disease Burden Epidemiology Reference Group (FERG): implementing strategy, setting priorities and assigning the tasks.

[3] Ogori AF and Utim SM. (2013). Nutrition as a food for family security. A review. Journal of Scientific and Innovation Research, 2(4), 824-827.

[4] Martins DJ. (2009). Differences in Odonata abundance and diversity in pesticide fished, traditionally-fished and protected areas in Lake Victoria, Eastern Africa (Anisoptera). Odonatologica, 38, 247-255.

[5] Poppenga RH. (2010). Volume 2: Clinical Toxicology. In: Luch A (Eds), Poisonous plants: Molecular, clinical and environmental toxicology. Birkhauser Verlag, Berlin, 123-176.

[6] Iwamoto M, Ayers T, Mahon BE and Swerdlow DL. (2010). Epidemiology of seafood-associated infections in the United States. Clinical Microbiology Reviews, 23(2), 399-411.

[7] Pennotti R, Scallan E, Backer L, Thomas J and Angulo FJ. (2013). Ciguatera and scombroid fish poisoning in the United States. Foodborne Pathogens and Disease, 10(12), 1059-1066. 
[8] Yu XZ. (2015). Uptake, assimilation and toxicity of cyanogenic compounds in plants: facts and fictions. Int J Environ Sci Tech, 12(2), 763-774.

[9] Travis SPL, Ahmad T, Collier J and Steinhart AH. (2005). Pocket consultant gastroenterology, Third edition. Blackwell Publishing, Oxford, UK, 349-354.

[10] Doorduyn Y, Van Den Brandhof WE, Van Duynhoven YT, Wannet WJ and Van Pelt W. (2006). Risk factors for salmonella enteritidis and typhimurium (DT104 and non- DT104) infections in the Netherlands: predominant roles for raw eggs in enteritidis and sandboxes in typhimurium infections. Epidemiol Infect, 134, 617-626.

[11] Do Vale A, Cabanes D and Sousa S. (2016). Bacterial Toxins as Pathogen Weapons Against Phagocytes. Frontiers in Microbiology, 7, 42.

[12] Popoff MR. (2014). Botulinum neurotoxins: more and more diverse and fascinating toxic proteins. J Infect Dis, 209(2), 168-169.

[13] Mc Lauchlin J and Grant KA. (2007). Clostridum botulinum and Clostridium perfringens. In: Simjee S (Eds), Foodborne Diseases. Humana Press, Totowa, 41-78.

[14] Seike S, Miyamoto K, Kobayashi K, Takehara M and Nagahama M. (2016). Clostridium perfringens delta-toxin induces rapid cell necrosis. PloS One, 11(1), e0147957.

[15] Hennekinne JA, De Buyser ML and Dragacci S. (2012). Staphylococcus aureus and its food poisoning toxins: characterization and outbreak investigation. FEMS Microbiol Rev, 36, 815-836.

[16] Johler S, Giannini P, Jermini M, Hummerjohann J, Baumgartner A and Stephan R. (2015). Further evidence for staphylococcal food poisoning outbreaks caused by egc-encoded enterotoxins. Toxins, 7, 997-1004.

[17] Logan NA. (2011). Bacillus and relatives in foodborne diseases. J Appl Microbiol, 112, 417-429.

[18] El-Arabi TF and Griffiths MW. (2013). Bacillus cereus. In: Morris JG and Potter ME, Foodborne infections and intoxications, Fourth edition. Academic Press - Elsevier, 401-407.

[19] Pitt JI. (2013). Mycotoxins. In: Morris JG and Potter ME, Foodborne infections and intoxications, Fourth edition. Academic Press - Elsevier, 409-418.

[20] WHO - World Health Organization. (2018). Natural toxins in food.

[21] Ogori AF. (2019). Plant Toxins. Am J Biomed Sci \& Res, 4(3), 173-175.

[22] Tchounwou PB, Yedjou CG, Patlolla AK and Sutton DJ. (2012). Heavy metals toxicity and the environment. Exp Suppl, 101, 133-164.

[23] Lindsey P, Balme G, Becker M, Begg C, Bento C, Bocchino C, Dickman A, Diggle R, Eves H, Henschel P, Lewis D, Marnewick K, Mattheus J, McNutt JW, McRobb R, Midlane N, Milanzi J, Morley R, Murphree M, Nyoni P, Opyene V, Phadima J, Purchase N, Rentsch D, Roche C, Shaw J, van der Westhuizen H, Van Vliet N and Zisadza P (2015). Illegal hunting and the bush-meat trade in savanna Africa: drivers, impacts and solutions to address the problem. Panthera/Zoological Society of Lon FAO, don/Wildlife Conservation Society report, New York. 79.

[24] Charritat JL, Corbineau D, Guth S, Meunier M, Pernin P and Pflieger H. (1992). Therapeutic evaluation of Mormoiron attapulgite in acute diarrheas of infants and children. A multicenter study in controlled liberal practice versus placebo in 113 patients. Ann Pediatr (Paris), 39(5), 326-332.

[25] Dodge AG and Wackett LP. (2005). Metabolism of Bismuth Subsalicylate and Intracellular Accumulation of Bismuth by Fusarium sp. Strain BI. Applied and Environmental Microbiology, 71(2), 876-82.

[26] Mearin F. (2006). Pharmacological treatment of the irritable bowel syndrome and other functional bowel disorders. Digestion, 73(suppl 1), 28-37.

[27] Yanai K. (2012). Anticholinergic activity of antihistamines. Clinical Neurophysiology, 123(4), 633-634.

[28] Pommier Y, Leo E, Zhang H and Marchand C. (2010). DNA topoisomerases and their poisoning by anticancer and antibacterial drugs. Chemistry \& Biology, 17(5), 421-33.

[29] WHO - World Health Organization. (2005). The treatment of diarrhoea: A manual for physicians and other senior health workers. World Health Organization (WHO), Geneva, Switzerland.

[30] Munos MK, Walker CL and Black RE. (2010). The effect of oral rehydration solution and recommended home fluids on diarrhoea mortality. International Journal of Epidemiology, 39(1), 75-87. 


\section{How to cite this article}

Moke EG, Edje KE, Toloyai PY, Anachuna KK and Ifezue CR. (2020). Causative agents and chemotherapy for food poisoning. World Journal of Advanced Research and Reviews, 6(1), 233-237. 